\title{
NEST-SITE SELECTION OF THE SYRIAN WOODPECKER (DENDROCOPOS SYRIACUS) IN THE AGRICULTURAL LANDSCAPE OF SE POLAND
}

\author{
Jerzy MichalczuK ${ }^{1}$ and Monika MichalczuK ${ }^{2}$ \\ ${ }^{1}$ Department of Nature Conservation and Landscape Ecology, University of Rzeszów \\ Zelwerowicza 4, 35-601 Rzeszów, Poland \\ E-mail: jurmich@ur.edu.pl; https://orcid.org/0000-0001-9311-7731 \\ ${ }^{2}$ Department of Nature Conservation and Landscape Ecology, University of Rzeszów \\ Zelwerowicza 4, 35-601 Rzeszów, Poland \\ E-mail:momich@ur.edu.pl; https://orcid.org/0000-0002-9298-3782
}

This paper presents the nest-site selection of the Syrian Woodpecker in the agricultural landscape of SE Poland. For this purpose, 89 locations of trees with excavated nest cavities were characterized by comparing the parameters of nest trees and non-nest trees located in the immediate vicinity of the nests in 2002-2006. The study showed that woodpeckers nest in trees that are thicker and in worse condition compared to other trees available in the environment. The birds also nested very close to residential buildings, and chose trees for nest cavity excavation that had drying or pruned boughs and branches. Research indicates that the Syrian Woodpecker may be sensitive to loss of thicker (more than $40 \mathrm{~cm}$ in diameter), dying and older trees aged 40-60 years. In addition, it may react negatively to increasing the share of non-forest coniferous trees, which it does not prefer for nesting.

Keywords: primary hole nesters, non-forest tree stands, nesting ecology, habitat requirements, bird conservation, Syrian Woodpecker, nest-site selection.

\section{INTRODUCTION}

The presence of suitable habitats is of key importance for the occurrence of woodpeckers in forests (e.g. Hågvar et al. 1990, Melletti \& Penteriani 2003, Kumar et al. 2014), as well as in areas with non-forest trees (MichaLczuk \& Michalczuk 2016c, Каjтоch \& Figarski 2017, Figarski \& КаJтоch 2018). For many species, the presence of older trees in the environment is important because they have larger dimensions and usually a poorer health condition (Melletti \& Penteriani 2003, Kosiński 2006, Grǘbler et al. 2013). The presence of such trees has a positive effect on the availability of foraging areas as well as suitable sites for nest construction (e.g. Glue \& Boswell 1994, Melletti \& Penteriani 2003, Czeszczewik 2009, Grüebler et al. 2013). It has been shown that woodpeckers often build nest cavities in sites where it is relatively easy for them to be excavated (Матsuока 2008). Dying or dead fragments of trees have been used for this purpose repeatedly (KosińsKi et al. 2006, Kosiński \& Kempa 2007, Damoc et al. 2014, but see also Hebda et al. 2017). 
Woodpeckers also favor trees with well-developed mycelia (PAsinelLI 2007), broken boughs or branches, as well as scars where boughs or branches have been pruned (WesoŁowski 1995, Grüebler et al. 2013). The birds also widely use softwood species, such as poplar (Populus sp.), alder (Alnus sp.), or willow (Salix sp.) (HÅgvar et al. 1990). The common Great Spotted Woodpecker (Dendrocopos major) often uses these tree species (GLuE \& Boswell 1994, Mazgajski 1998, Hebda et al. 2017), as does the Syrian Woodpecker (Dendrocopos syriacus), in non-forest tree plantings (Michalczuk \& Michalczuk 2016c).

Due to the common occurrence and considerable prevalence of the Great Spotted Woodpecker (Glutz von Blotzheim \& Bauer 1980, Cramp 1985, Flade 1997), many studies have been conducted on its nesting requirements (e.g. GLUE \& Boswell 1994, Kosiński et al. 2006, Damoc et al. 2014, Hebda et al. 2017). In contrast to the Great Spotted Woodpecker, knowledge about the Syrian Woodpecker is still sparse, as it is the least studied European woodpecker (PAsINELLI 2006). After its dynamic expansion (Zavialov et al. 2008, Michalczuk 2014), this species is currently decreasing in some regions of Europe (BIRDLife INternational 2004, Hristov \& Petkov 2013, EBCC 2013), including SE Poland (Michalczuk et al. 2011, Michalczuk \& Michalczuk 2015, Michalczuk et al. 2018). The observed decline in population size can be linked to the negative changes occurring in non-forest tree plantings (Michalczuk \& MichalczuK 2015), which this species prefers (Michalczuk \& Michalczuk 2016c, Кajtoch \& Figarski 2017, Figarski \& KaJTOCH 2018). In studies to date on Syrian Woodpecker habitats, macro-habitat parameters, such as, for example, the share and type of afforestation within territories (CіACH \& FröHlich 2013, MichalczUK \& Michalczuk 2016c, d, Kajtoch \& Figarski 2017), were most often analyzed, and only rarely were its nesting preferences assessed (AgHANAJAFIZADEH $e t$ al. 2011, Michalczuk \& Michalczuk 2016e). An important issue, therefore, is to determine the ecological requirements of the Syrian Woodpecker, which can provide the key knowledge required to plan its protection.

This study aimed to identify the preferences of nesting Syrian Woodpecker in the agricultural landscape of SE Poland. For this purpose, the locations of trees with excavated nest cavities were characterized, and the parameters of nest trees and non-nest trees located in the immediate vicinity of the nests were compared, which may help to point out recommendations for the protection of this species' nesting habitat.

\section{MATERIAL AND METHODS}

\section{Study area}

The study area consisting of $305 \mathrm{~km}^{2}$ was located near Tomaszów Lubelski in southeastern Poland $\left(50^{\circ} 28^{\prime} \mathrm{N}, 23^{\circ} 40^{\prime} \mathrm{E}\right)$. This area is an agricultural landscape, characterized by 
gently rolling hills in the range of 195-263 m above sea level. It is part of the Sokal PlateauRidge, which is part of the Volhynian Upland (KоNDracki 2000). Due to the presence of very fertile soils, arable soils predominate here (BAŃsKi 2010), constituting about $75 \%$ of the area. Meadows cover about $15 \%$ and occur mainly in the valleys of small rivers, the largest of which is the Huczwa. Forests in the research area are heavily fragmented and occupy less than $5 \%$ of the area. Non-forest plantings occupy about $3 \%$ of the study area. They are found mainly around residential buildings, but also in arable fields and meadows. They include mainly orchards, gardens and groups of trees. Rarely, there are tree rows and alleys and sporadically parks and cemeteries (for more details, see Michalczuк \& Michalczuк 2016a, b).

\section{Searching for nest cavities}

The research was conducted in 2002-2006. The search for woodpecker nests occurred between March and July (for methodical details see Michalczuk \& Michalczuk 2006a, $b$, Michalczuk et al. 2011). Mainly males were observed in designated breeding territories, as they usually excavate the nest cavities as well as defend them against competitors (MICHALCZUK \& Michalczuk 2016b). Birds behaving territorially, as well as those carrying food for nestlings, were also observed during the breeding season. After the eventual loss of a nest cavity, the search for successive nest cavities excavated by the given pair was continued. In cases when it was difficult to detect individuals in previously delineated territories, all tree stands were searched. At that time, attention was paid to fresh wood chips found on the bark of trees or on the ground, evidence of a new nest cavity being excavated or an old one being improved. Old nests were also checked, and trees with cavities excavated in previous years were inspected. Only isolated cases were noted of brood loss due to the parasitism of the starling (Sturnus vulgaris) in re-used old nests or newly excavated ones. These nest cavities were included in the calculations only once. A total of 89 nest trees were assessed.

\section{Description of the nest trees}

Breeding sites were described after the nestlings left the nest cavity. During the field work, species of trees with nest cavities were identified. Then, based on the knowledge about the management introduced by humans in the tree stands, the nest trees were classified into two groups. The first group included fruit trees, mainly apple, cherry, walnut, plum or sour cherry. The above mentioned tree species were planted mostly in orchards and they very often had scars, as derivatives of pruning of limbs and branches. They delivered a dry substrate, which is widely used by woodpeckers for hole excavation. For this reason, these species of trees were bound into one group and named in our study as a "orchard species trees". Other tree species (including mainly willows and poplars), which mainly displayed broken boughs or branches and primarily occurred outside of orchards, were named as "non-orchard species" trees. The diameter of the tree trunk (DBH) was measured at the height of $1.3 \mathrm{~m}$. Some of these measurements from 2002-2005 were presented in another paper (Michalczuk \& Michalczuk 2016e).

The distance to the nearest building was also measured for trees with a nest. The same procedure was done for 441 random selected tree points (for details, see Michalczuk \& Michalczuk 2006a). For this purpose, a measuring tape was mainly used. For nest cavities located at a considerable distance from buildings, e.g. in forests, measurements were made based on the geographical coordinates determined by using a GPS receiver. Then 
the distance was measured using orthophoto maps from the Geoportal website (www. geoprtal.gov.pl). The age of the trees in which the birds nested was also determined during the study. For this purpose, interviews were conducted with landowners or residents, who provided information on the age of the trees in which the woodpeckers had excavated nest cavities. In the case of nests located in forests, such information was taken from maps showing the age of the tree stands, available on the Forest Data Bank website (FDB 2016).

The condition of the trees was assessed on a seven-point scale, in which the health of a tree diminishes in successive stages (according to HÅGVAR et al.1990, MAZGAJSKI 1998, Table 1). In addition, nest trees were also assessed as to whether they had broken boughs or branches and whether they had signs of pruning in the form of scars after boughs and branches had been removed, which may be important in excavating cavities and in the selection of nest sites (e.g. WesoŁowsKi 1995, GRÜEBLER et al. 2013).

During the field work, the sites of excavated nest cavities on the tree were also described. For this purpose, three zones were distinguished: the trunk, the transition from the trunk to the crown (when the entry of the nest was in the lowest branch and the nest chamber was in the trunk) and the tree crown. The condition of the site where the nest cavity was excavated was also described, with these locations divided into three categories: 1 - locations in a healthy area with no signs of dieback, 2 - excavations in fragments of the tree with partly dead wood, but still with living bark and branch shoots, 3 - in places with dead wood.

\section{Assessment of the area surrounding the nest site}

To characterize the trees in the closest vicinity to the nest tree, a circle with a radius of $20 \mathrm{~m}$ was measured around it. Within these designated areas $(n=87)$, trees with a diameter $(\mathrm{DBH})$ equal to and larger than $16 \mathrm{~cm}$ were measured at $1.3 \mathrm{~m}$ above the ground surface. Syrian Woodpeckers can excavate cavities in trees of such dimensions, which is why they are potentially suitable for nesting, and their presence may determine the nesting site choice of the bird (MichalczuK \& Michalczuk 2016e). The trunk diameter was measured of all such trees $(n=1083)$. The health condition of 248 trees around the 22 nest sites detected only in 2006 also assessed using the seven-point scale (see the previous description in Table 1).

\section{Calculations and statistical analysis}

When assessing the nesting preferences of woodpeckers in relation to the building location, dimensions and health condition of trees, the "individual selection index" (MANLY et al. 1993) was used. In the case of the dimensions and health condition of trees, this is the quotient calculated from the share of nest trees individually categorized to ranges of trunk diameter sizes (DBH 16-20, 21-40, 41-60, 61-80, 81-100 and >100 cm, Table 2) or health classes (from 1 to 7 , see Tables 1 and 3 ) in relation to the share of a given tree class located in the area surrounding the nest trees (within a radius of 20 meters from the nest tree). For assessment of woodpecker nest site preferences towards the location of buildings, the placement of nest trees was related to the locations of 441 trees randomly selected in the entire study area. Six distance classes were determined for this analysis: $<10,11-30,31-50$, 51-100, 101-200, and > $200 \mathrm{~m}$ (Table 4). Based on Bonferroni's inequality, a concurrent 95\% confidence interval (CI) was constructed for the selection index. If the obtained confidence interval was greater than 1, this meant that the tree species or class was preferred, and when it was less than 1 , it meant that the woodpeckers avoided a given species or class of 
Table 1. Level of the health condition of trees (according to HÅgvar et al. 1990, MAZGAJSKI 1998, modified).

\begin{tabular}{|c|c|c|c|c|}
\hline \multirow{2}{*}{\multicolumn{2}{|c|}{$\begin{array}{l}\text { Tree } \\
\text { health } \\
\text { scale }\end{array}$}} & \multirow{3}{*}{$\begin{array}{c}\text { Tree } \\
\text { damage } \\
\% \\
\leq 10\end{array}$} & \multicolumn{2}{|c|}{ Tree damage/health condition of the tree } \\
\hline & & & \multirow{2}{*}{$\begin{array}{l}\text { Trunk } \\
\text { bark has no dam- } \\
\text { age, very sporadic } \\
\text { cracks found }\end{array}$} & \multirow{2}{*}{$\begin{array}{l}\text { Crown } \\
\text { all branches have live buds or leaves, } \\
\text { no damaged bark }\end{array}$} \\
\hline 1 & healthy & & & \\
\hline 2 & $\begin{array}{l}\text { declin- } \\
\text { ing }\end{array}$ & $11-30$ & $\begin{array}{l}\text { bark is cracked to a } \\
\text { small degree }\end{array}$ & $\begin{array}{l}\text { most branches are living, but there are } \\
\text { signs of dying in the form of dry tops } \\
\text { of branches and leaves }\end{array}$ \\
\hline 3 & $\begin{array}{l}\text { weak- } \\
\text { ened }\end{array}$ & $31-50$ & $\begin{array}{l}\text { bark is cracked over } \\
\text { a significant share } \\
\text { of its area, small } \\
\text { areas lack bark }\end{array}$ & $\begin{array}{l}\text { single boughs or a large share of the } \\
\text { thin branches are dry, there may be } \\
\text { cracks on the bark of thicker branches } \\
\text { and mycelium, some branches have } \\
\text { been pruned }\end{array}$ \\
\hline 4 & sick & $51-70$ & $\begin{array}{l}\text { significant areas } \\
\text { of bark coming off } \\
\text { the trunk, sporadic } \\
\text { presence of myce- } \\
\text { lium }\end{array}$ & $\begin{array}{l}\text { a large share of the thin branches are } \\
\text { dry, thicker branches are dying and } \\
\text { losing their bark, sometimes mycelium } \\
\text { growth is observed, a large share of the } \\
\text { boughs have been pruned }\end{array}$ \\
\hline 5 & dying & $71-99$ & $\begin{array}{l}\text { large areas of the } \\
\text { trunk lack bark, fre- } \\
\text { quent presence of } \\
\text { mold and mycelium }\end{array}$ & $\begin{array}{l}\text { the vast majority of branches and thick } \\
\text { boughs are dry, only a few branches } \\
\text { are living, quite often patches of decay } \\
\text { are encountered in the boughs and } \\
\text { mycelium is present, a large share of } \\
\text { the branches have been pruned }\end{array}$ \\
\hline & dead & 100 & \multicolumn{2}{|c|}{$\begin{array}{l}\text { dead hardwood tree, bark coming off the trunk, dry leaves, } \\
\text { mycelium is often present }\end{array}$} \\
\hline & dead & 100 & \multicolumn{2}{|c|}{$\begin{array}{l}\text { dead softwood and decaying tree, bark coming off the crown } \\
\text { and trunk, developed mycelium }\end{array}$} \\
\hline
\end{tabular}

trees. Confidence intervals of the individual selection indices containing a value of 1 meant that the woodpecker had no preference for a given tree species or type. The negative lower limit of the confidence intervals was changed to 0.00 because negative values of confidence intervals are not possible.

The collected data were used to compare the parameters of nest trees and potentially suitable trees for nesting, i.e. those occurring in the closest vicinity of the nest tree. The MannWhitney $U$ test was used to compare the average dimensions of trunk diameters and the average health status of nest trees as well as the trees in the vicinity of the nest. The same test was used to the comparison of the distance to the nearest building for nest trees and randomly selected trees. The chi-square test with the Yates correction was used to assess the frequency of the use of trees with pruning cuts or broken branches (which were divided into two basic groups: "orchard tree species" and "non-orchard tree species"), as well as the frequency of the use of conifers. Differences were assumed to be significant at the level of $p<0.05$. 


\section{RESULTS}

The average diameter of the trees in which woodpeckers built nests was $44.9 \mathrm{~cm}(\mathrm{SD} \pm 21,0, \mathrm{n}=89), 15 \mathrm{~cm}$ greater than the diameter of the trees surrounding the nest tree (mean 29.7, $\mathrm{SD} \pm 14.7, \mathrm{n}=1083$, Mann-Whitney $\mathrm{U}$ test $\mathrm{Z}=-8.49, \mathrm{p}<0.0001)$. Woodpeckers used thinner trees with diameters of $16-$ $20 \mathrm{~cm}$ or $21-40 \mathrm{~cm}$ in accordance with their availability in the environment (Table 2). Woodpeckers used mostly thicker trees for excavating nest cavities, whose diameter exceeded $40 \mathrm{~cm}$, and those with trunks thicker than $60 \mathrm{~cm}$ were preferred (Table 2).

Nest trees also had a significantly poorer health status (an average of 4.0 on a seven-point scale, $\mathrm{SD} \pm 1.11, \mathrm{n}=89$ ) than the surrounding trees (mean 2.8, $\mathrm{SD} \pm 1.40, \mathrm{n}=248$ ), and these differences were statistically significant (MannWhitney $U$ test $Z=-7.07, p<0.0001$ ). Only infrequently did the Syrian Woodpecker build nests in healthy trees (category 1), slightly infested trees (category 2), or in dead trees (categories 6 and 7). Trees in these health condition categories were not preferred by this species, neither were weakened trees (category 3), whose use was already greater (about 24\%, Table 3). The birds nested most often in diseased and dying trees (health condition categories 4 and 5), which were already preferred by woodpeckers (Table 3 ). These were mostly dying trees whose branches had been pruned, infected with mycelium or with broken boughs and branches. The woodpeckers excavated the majority of nests $(91.0 \%, \mathrm{n}=89$ ) in such dying fragments (with partially dry and dead wood). The birds nested in areas with healthy wood $(7.9 \%)$ or in the dead parts of trees $(1.1 \%)$ only exceptionally. In the case of using "orchard species" trees for nesting, pruning scars were found more frequently $(83 \%$, $\mathrm{n}=53)$ compared to "non-orchard species" trees $(33 \%, \mathrm{n}=36$, Yates corrected chi-square test $=20.60, \mathrm{df}=1, \mathrm{p}<0.0001$ ). In the case of the latter group of nest trees (in which poplars and willows dominated, constituting $67 \%$ in total,

Table 2. Share of trees with various sizes of trunks used by Syrian Woodpeckers for nesting in view of their availability in the vicinity of the nest sites.

\begin{tabular}{ccccccc}
\hline $\begin{array}{c}\text { Tree trunk } \\
\text { diameter }(\mathrm{cm})\end{array}$ & $\begin{array}{c}\text { Nests } \\
(\mathrm{n}=89)\end{array}$ & $\begin{array}{c}\text { Propor- } \\
\text { tion of } \\
\text { nests }\end{array}$ & $\begin{array}{c}\text { Available } \\
\text { trees } \\
(\mathrm{n}=1083)\end{array}$ & $\begin{array}{c}\text { Proportion } \\
\text { of available } \\
\text { trees }\end{array}$ & $\begin{array}{c}\text { Selection } \\
\text { index }\end{array}$ & 95\% CL \\
\hline $16-20$ & 3 & 0.034 & 357 & 0.330 & 0.103 & $0.00-1.61$ \\
$21-40$ & 47 & 0.528 & 548 & 0.506 & 1.043 & $0.78-1.31$ \\
$41-60$ & 23 & 0.258 & 134 & 0.124 & 2.081 & $1.60-2.56$ \\
$61-80$ & 10 & 0.112 & 28 & 0.026 & 4.308 & $3.51-5.10$ \\
$81-100$ & 4 & 0.045 & 10 & 0.009 & 5.000 & $3.70-6.30$ \\
$>100$ & 2 & 0.022 & 6 & 0.006 & 3.667 & $1.79-5.55$ \\
\hline
\end{tabular}


Table 3. Share of trees of various health condition used by Syrian Woodpecker for nesting in view of their availability in the vicinity of the nest sites.

\begin{tabular}{ccccccc}
\hline $\begin{array}{c}\text { Tree condi- } \\
\text { tion (degrees } \\
\text { scale) }\end{array}$ & $\begin{array}{c}\text { Nests } \\
(\mathrm{n}=89)\end{array}$ & $\begin{array}{c}\text { Propor- } \\
\text { tion of } \\
\text { nests }\end{array}$ & $\begin{array}{c}\text { Available } \\
\text { trees } \\
(\mathrm{n}=248)\end{array}$ & $\begin{array}{c}\text { Proportion } \\
\text { of available } \\
\text { trees }\end{array}$ & $\begin{array}{c}\text { Selection } \\
\text { index }\end{array}$ & 95\% CL \\
\hline 1 & 1 & 0.011 & 53 & 0.214 & 0.051 & $0.00-2.73$ \\
2 & 8 & 0.09 & 64 & 0.258 & 0.349 & $0.00-1.25$ \\
3 & 21 & 0.236 & 64 & 0.258 & 0.915 & $0.41-1.42$ \\
4 & 26 & 0.292 & 37 & 0.149 & 1.960 & $1.52-2.40$ \\
5 & 30 & 0.337 & 21 & 0.085 & 3.965 & $3.56-4.36$ \\
6 & 2 & 0.022 & 6 & 0.024 & 0.917 & $0.00-2.80$ \\
7 & 1 & 0.011 & 3 & 0.012 & 0.917 & $0.00-3.59$ \\
\hline
\end{tabular}

$\mathrm{n}=36)$, broken branches and boughs were recorded more frequently (13\% vs $61 \%$, Yates corrected chi-square test $=6.48, \mathrm{df}=1, \mathrm{p}=0.0109)$. Woodpeckers also avoided nesting in coniferous trees. Only one case of nesting was observed in a spruce Picea abies (frequency approx. $1 \%, \mathrm{n}=89$ ). The presence of conifers in the nest trees' vicinities was statistically higher (Yates corrected chisquare test $=4.21, \mathrm{df}=1, \mathrm{p}=0.0401)$ and was amounted to approx. $9 \%(\mathrm{n}=89)$.

Woodpeckers located their nests in close proximity to human settlements in relation to randomly selected trees (Table 4 ). The average distance between nest trees and buildings was $38.4 \mathrm{~m}(\mathrm{SD} \pm 78.4, \mathrm{n}=89)$ and was statistically smaller in comparison to distance determined for randomly selected trees (mean $210.8 \mathrm{~m}, \mathrm{SD} \pm 272.6, \mathrm{n}=441$; Mann-Whitney $\mathrm{U}$ test $\mathrm{Z}=8.08, \mathrm{p}<0.0001$ ). The vast majority (as many as $42.7 \%$ ) of nests were located within $10 \mathrm{~m}$ of a building, and some nests were located even $35 \mathrm{~cm}$ away from building walls. Only this range was preferred by the Syrian Woodpecker for nesting (Table 4).

Table 4. Share of the location of the Syrian Woodpecker nest tree sites and random selected tree sites at different distance ranges from buildings

\begin{tabular}{ccccccc}
\hline $\begin{array}{c}\text { Distance } \\
(\mathrm{m})\end{array}$ & $\begin{array}{c}\text { Nest sites } \\
(\mathrm{n}=89)\end{array}$ & $\begin{array}{c}\text { Proportion } \\
\text { of nest sites }\end{array}$ & $\begin{array}{c}\text { Available } \\
\text { tree sites } \\
(\mathrm{n}=441)\end{array}$ & $\begin{array}{c}\text { Proportion } \\
\text { of available } \\
\text { tree sites }\end{array}$ & $\begin{array}{c}\text { Selection } \\
\text { index }\end{array}$ & 95\% CL \\
\hline$<10$ & 38 & 0.427 & 58 & 0.132 & 3.235 & $2.91-3.56$ \\
$11-30$ & 28 & 0.315 & 107 & 0.243 & 1.296 & $0.88-1.71$ \\
$31-50$ & 9 & 0.101 & 45 & 0.102 & 0.990 & $0.15-1.83$ \\
$51-100$ & 5 & 0.056 & 37 & 0.084 & 0.667 & $0.00-1.82$ \\
$101-200$ & 4 & 0.045 & 40 & 0.091 & 0.495 & $0.00-1.79$ \\
$>200$ & 5 & 0.056 & 154 & 0.349 & 0.160 & $0.00-1.31$ \\
\hline
\end{tabular}


Quite often (31.5\%), birds also nested in the range of 10-30 $\mathrm{m}$ from buildings. Much less frequently, woodpeckers excavated cavities at a distance of over 50 $\mathrm{m}$ from buildings (15.7\%). The farthest nest was in a forest, about $550 \mathrm{~m}$ away from the nearest dwellings.

Woodpeckers excavated cavities mainly in the tree crown, where $73.0 \%$ of the nests were located. Only $14.6 \%$ of the nest cavities were located in the trunk, and $12.4 \%$ of the nests were found in the transition area of trunk to crown. Syrian Woodpeckers used mainly 40-60 years old trees for nesting, $52.8 \%(n=89)$ of all nest trees. Young growth trees in the $20-40$ years of age range $(38.2 \%)$ were used less often, and those less than 20 years of age $(2.2 \%)$ were used even less frequently. The use of trees aged $60-80$ years $(4.5 \%)$ or older $(2.2 \%, \mathrm{n}=89)$ was also the exception.

\section{DISCUSSION}

The Syrian Woodpecker in the studied area used the more stately trees for nesting among available ones in the environment. Such dependencies have already been confirmed in the Polish agricultural landscape (Michalczuk \& Michalczuk 2016e), as well as in the areas from which the species originally extended its range, e.g. Iran (Aghanajafizadeh et al. 2011). The tendency to use the more stately trees in the habitat was also confirmed in urban habitat (FigaRsKi \& KaJTOCH 2018) and is visible in the case of other woodpeckers, e.g. Great Spotted and Middle Spotted Woodpeckers (e.g. Pasinelli 2007, Kosiński et al. 2006, but see Ćiкović et al. 2014). Although the diameter of the Syrian Woodpecker's nest trees were within the size limits of those occupied by both of the previously mentioned species (average trunk diameter 33-62 cm, Kosiński et al. 2006, Kosińsкi \& Kempa 2007, Ćíović et al. 2014, Hebda et al. 2017), the sites used differ by the qualities of the habitat, which is seen in the results of the cited studies. In the case of the Syrian Woodpecker, one of the most important habitat features is the type of tree stand in which the birds nested. Nest tree diameters can be very diverse (e.g. along avenues and in orchards), due, among others, to the large diversity of tree dimensions found in particular types of tree stands (Michalczuk \& Michalczuk 2016e). Such dependencies were also confirmed in studies of other woodpeckers. In natural and protected forests, the nest trees of the Great Spotted and Middle Spotted Woodpeckers usually had larger dimensions than those in areas with commercial tree stands (MAZgajski 1998, Kosiński \& Winiecki 2004, Kosiński et al. 2006, PAsinelli 2007). As suggested by the authors, the given differences were derived from the various tree resources in the specified areas. This correlation is also confirmed in studies on the Syrian Woodpecker, which indicates that 
the thinner the trees of a given species, the thinner the trees chosen for nesting (Michalczuk \& Michalczuk 2016e).

The more frequent use of larger and older trees by the Syrian Woodpecker may be associated with the health condition of these trees. Because of their age (most often they were about $40-60$ years old), about $87 \%$ of trees were characterized by low health oscillating around category 3-5 on the seven-point scale, in which tree health decreases in subsequent categories. Earlier research (Walankiewicz et al. 2002, Kosiński \& Winiecki 2005, CzeszczewiK \& Walankiewicz 2006, KosińsKi \& Kempa 2007) confirms that the presence of weakened and even dead trees is one of the most important factors determining the occurrence of woodpeckers. In the studied Syrian Woodpecker population, "orchard species" mainly fruit trees were often used for nesting, which due to pruning, were characterized by scars where the branches had been removed (about $83 \%$ of trees). The trend of using fruit trees is also seen in studies performed at other latitudes. In West Asia, the Syrian Woodpecker colonized mainly citrus or ornamental trees (AL-SAFADi 2004, Ar et al. 2004), whereas in natural forests, this species occupies habitats dominated by Common Hornbeam Carpinus betulus and Oriental Beech Fagus orientalis (KHANAposhtani et al. 2012). In Vojvodina, it often occupied Mulberry Trees Morus spp. (Szlivka 1957, 1962), and in Austria, Walnuts Juglans regia (Ruge 1969). Although the authors suggest that the choice of these species was dictated by the fact that these trees were the most common in the studied area (e.g. SzLIVKA 1957, 1962, RUGE 1969), it can be assumed that they had not only cracks but probably also scars from pruned boughs and branches, contributing to the creation of appropriate sites for excavating a cavity (GRÜEBLER et al. 2013).

As research has shown, the Syrian Woodpecker often uses (frequency of $61 \%$ ) other trees that have broken branches or boughs, are dying, partially dead or have dry fragments to build a nest. Such sites are often used for nesting by other species (Hågvar et al. 1990, WesoŁowski 1995, Mazgajski 1998, KosiŃSKI \& KEMPA 2007). This is significant, especially for woodpeckers with weaker neck muscles, whose body construction somewhat restricts the ability to excavate cavities in hard wood. This was noted many times in comparisons of the nest preferences of the Great Spotted Woodpecker, which is stronger, and the weaker Middle Spotted and Lesser Spotted Woodpeckers (Hågvar et al. 1990, Kosiński et al. 2006, Kosiński \& Kempa 2007). The weaker body structure of the smaller species also forces the birds to excavate nests in higher parts of the tree. According to research from North America (Schepps et al. 1999), higher tree zones, e.g. the wood of the boughs and branches in the higher tree zones, is not as hard as in the tree trunk, which improves the chance that a cavity can be excavated, especially for the "weaker" species. 
Similar behaviors can also be found in the studied population of the Syrian Woodpecker. It was found that almost $3 / 4$ of the nests were located in the tree crown, and only exceptionally were they located in trunks. This is in opposition to observations of this species in Vojvodina and Austria (SzLIvkA 1957, 1962, RUGE 1969), where most cavities were located in tree trunks. A similar tendency was also observed for the Great and Middle Spotted Woodpeckers, in which the share of nests excavated in trunks ranged from 52-92\% (Mazgajski 1998, Kosiński et al. 2006, Kosiński \& Kempa 2007, Hebda et al. 2017). We can conclude from our research that the Syrian Woodpecker - by placing its nest in the canopy - probably minimize energy expenses and the time needed to build a nest. Such an adaptation allows the woodpeckers to breed again after an eventual loss of a nest cavity, e.g. as the result of starling parasitism, when the birds have to quickly excavate another one (SzLivkA 1957, 1962, Michalczuk \& Michalczuk 2016a, b).

This study has shown that the Syrian Woodpecker is a synanthropic species because it nested close to buildings. In other regions, studies also found that it often excavated cavities in trees located up to several meters from residential buildings (Szlivka 1957, 1962, Ruge 1969). Despite the fact that this species is ecologically flexible because it can colonize various trees close to humans (Michalczuk \& Michalczuk 2016c, e, d), it may be at risk due to negative changes in its habitats. This may be related to the loss of non-forest tree stands, and the agricultural landscape is particularly affected by the degradation or liquidation of orchards (Michalczuk \& Michalczuk 2015). Research shows that this species may be particularly sensitive to the loss of thicker (over $40 \mathrm{~cm}$ in diameter), dying and older trees aged 40-60 years.

The obtained results, as well as information available in the literature (e.g. Szlivka 1957, 1962, Ruge 1969), clearly indicate that the Syrian Woodpecker also avoids conifers. During the study, only once was breeding found in a cavity excavated in a Norway Spruce located in a garden. This species was also rarely found foraging in European Larch (Larix decidua) and the Northern White Cedar (Thuja occidentalis) (Glutz von Blotzheim \& Bauer 1980, Michalczuk \& Michalczuk 2005). These observations suggest that the Syrian Woodpecker may additionally be sensitive to changes occurring in non-forest tree plantings, which are also tending towards increases in the share of conifers.

The study has shown, that the protection of Syrian Woodpecker habitats should be predominantly carried out within human settlements, because tree stands located among residential buildings constitute the fundamental habitat of this species in the rural landscape. However, in order to protect the nesting habitats of the Syrian Woodpecker, the preservation of older trees in poorer health condition is needed. Taking into account that the Syrian Woodpecker is the dominant primary cavity nester in non-forest tree stands (MichalczuK 
et al. 2018), this species also plays an important role as the crucial provider of nest sites for secondary cavity nesters in anthropogenic habitats (e.g. SzLIVKA 1957, 1962, Gorman 2004, Michalczuk \& Michalczuk 2016a). The protection of tree stands providing for requirements of the Syrian Woodpecker should, therefore, preserve habitats for other species and, at the same way, also positively affect the biodiversity in the agricultural landscape.

\section{REFERENCES}

Aghanajafizadeh, A., Heydari, F., Naderi, G. \& Hemami, M. R. (2011): Nesting hole site selection by the Syrian Woodpecker, Dendrocopos syriacus, in Yazad province, Iran. - Zoology in the Middle East 53: 3-6. https://doi.org/10.1080/09397140.2011.10638494

Al-SAFADI, M. M. (2004): On the breeding biology of the Syrian Woodpecker, Dendrocopos syriacus, in the Gaza Strip. - Zoology in the Middle East 32: 7-12. https://doi.org/10.10 80/09397140.2004.10638038

Ar, A., Barnea, A., Yom-Tov, Y. \& Mersten-Katz, C. (2004): Woodpecker cavity aeration: a predictive model. - Respiratory Physiology E Neurobiology 144: 237-249. https://doi. org/10.1016/j.resp.2004.04.019

Bański, J. (ed.) (2010): Atlas Rolnictwa Polski [Atlas of Polish Agriculture]. - IGiPZ PAN, Warsaw, 126 pp. [in Polish]

BIRDLIFE INTERNATIONAL. (2004): Birds in Europe: population estimates, trends and conservation status. Conservation Series No. 12. - BirdLife International, Cambridge, 374 pp.

Ciach, M. \& Fröhlich, A. (2013): Habitat preferences of the Syrian Woodpecker Dendrocopos syriacus in urban environments: an ambiguous effect of pollution. - Bird Study 60: 491-499. https://doi.org/10.1080/00063657.2013.847899

Cramp, S. (ed.) (1985): The birds of the Western Palearctic. Vol. IV. - Oxford University Press, $958 \mathrm{pp}$.

Czeszczewik, D. (2009): Foraging behaviour of White-backed Woodpeckers Dendrocopos leucotos in a primeval forest (Białowieża National Park, NE Poland): dependence on habitat resources and season. - Acta Ornithologica 44: 109-118. https://doi. org/10.3161/000164509X482687

CzeszczewiK, D. \& Walankiewicz, W. (2006): Logging and distribution of the White-backed Woodpecker Dendrocopos leucotos in the Białowieża Forest. - Annales Zoologici Fennici 43: 221-227. http://www.jstor.org/stable/23735932

Ćíović, D., Barišić, S., Tutiš, V. \& KralJ, J. (2014): Nest site and nest-hole characteristics used by Great Spotted Woodpecker Dendrocopos major L. in Croatia. - Polish Journal of Ecology 62: 349-360. https://doi.org/10.3161/104.062.0213

Damoc, I., Sahlean, T., Ion, R., Ion, M. \& Meșter, L. E. (2014): Nesting preferences for two woodpecker species (Dendrocopos major and Dendrocopos medius) in Comana Forest, Southern Romania. - Travaux du Muséum National d'Histoire Naturelle Grigore Antipa 57: 35-45. https://doi.org/10.2478/travmu-2014-0004

EBCC (2013): Population trends of common European breeding birds 2013. - European Bird Census Council. www.ebcc.info [accessed 2014.11.22]

FDB (2016): Bank danych o lasach [Forest Data Bank]. www.bdl.lasy.gov.pl [accessed 2016.11.22] [in Polish] 
Figarski, T. \& KaJToch, Ł. (2018): Differences in habitat requirements between two sister Dendrocopos woodpeckers in urban environments: implication for the conservation of Syrian Woodpecker. - Acta Ornithologica 53: 23-36. https://doi.org/10.3161/000164 54AO2018.53.1.003

Flade, M. (1997): Dendrocopos major Great Spotted Woodpecker. Pp. 448-449. In: HageMEIJER, W. J. M. \& BlaIR, M. J. (eds): The PECBMS atlas of European breeding birds: Their distribution and abundance. - Tand A D Poyser, London.

Glue, D. E. \& Boswell, T. (1994): Comparative nesting ecology of the three British breeding woodpeckers. - British Birds 87: 253-269.

Glutz von Blotzheim, U. N. \& Bauer, K. (eds) (1980): Handbuch der Vögel Mitteleuropas. Vol. 9. - Akademische Verlag, Wiesbaden.

Gorman, G. (2004): Woodpecker nest holes. - Alula 3: 122-125.

Grüebler, M. U., Shaller, S., Keil, H. \& Naef-Daenzer, B. (2013): The occurrence of cavities in fruit trees: effects of tree age and management on biodiversity in traditional European orchards. - Biodiversity and Conservation 22: 3233-3246. https://doi. org/10.1007/s10531-013-0581-6

Hågvar, S., Hågvar, G. \& Mønness, E. (1990): Nest site selection in Norwegian woodpeckers. - Holarctic Ecology 13: 156-165. https://www.jstor.org/stable/3682641

Hebda, G., WesoŁowski, T. \& Rowiński, P. (2017): Nest sites of a strong excavator, the Great Spotted Woodpecker Dendrocopos major, in a primeval forest. - Ardea 105: 61-71. https://doi.org/10.5253/arde.v105i1.a8

Hristov, I. \& Petkov, N. (2013): State of common birds in Bulgaria 2005-2011. Bulgarian Society for the Protection of Birds. - Conservation series. Book 26, BSPB, Sofia.

Kajtoch, Ł. \& Figarski, T. (2017): Comparative distribution of Syrian and great spotted woodpeckers in different landscapes of Poland. - Folia Zoologica 66: 29-36. https:// doi.org/10.25225/fozo.v66.i1.a5.2017

Khanaposhtani, M. G., Kaboli, M., Karami, M. \& Etemad, V. (2012): Effect of habitat complexity on richness, abundance and distributional pattern of forest birds. - Environmental Management 50: 296-303. https://doi.org/10.1007/s00267-012-9877-7

Kondracki, J. (2000): Geografia regionalna Polski [Regional geography of Poland]. - Wyd. Nauk. PWN, Warsaw, 450 pp. [in Polish]

Kosiński, Z. (2006): Factors affecting the occurrence of Middle Spotted Woodpeckers revealed by forest inventory data. - Annales Zoologici Fennici 43: 198-210. https://www. jstor.org/stable/23735930

Kosiński, Z. \& Kempa, M. (2007): Density, distribution and nest sites of woodpeckers Picidae, in a managed forest of Western Poland. - Polish Journal of Ecology 53: 519-533.

Kosiński, Z., Ksit, P. \& Winiecki, A. (2006): Nest site of Great Spotted Woodpeckers Dendrocopos major and Middle Spotted Woodpeckers Dendrocopos medius in nearnatural and managed riverine forests. - Acta Ornithologica 41: 21-32. https://doi. org/10.3161/068.041.0108

KosińsKI, Z. \& Winiecki, A. (2004): Nest-site selection and niche partitioning among Great Spotted Woodpecker Dendrocopos major and Middle Spotted Woodpecker Dendrocopos medius in riverine forest of Central Europe. - Ornis Fennica 81: 145-156.

Kosiński, Z. \& Winiecki, A. (2005): Factors affecting the density of the middle spotted woodpecker Dendrocopos medius: a macrohabitat approach. - Journal of Ornithology 146: 263-270. https://doi.org/10.1007/s10336-005-0088-3 
Kumar, R., Shahabuddin, G. \& Kumar, A. (2014): Habitat determinants of woodpecker abundance and species richness in sub-Himalayan dipterocarp forests of north-west India. - Acta Ornithologica 49: 243-256. https://doi.org/10.3161/173484714X687136

Manly, B., McDonal, L. \& Thoma, D. (1993): Resource selection by animals. Statistical design and analysis for field studies. - Chapman and Hall, London. 177 pp.

MatsuoKa, S. (2008): Wood hardness in nest trees of the Great Spotted Woodpecker Dendrocopos major. - Ornithological Science 7: 59-66. https://doi.org/10.2326/13470558(2008)7[59:WHINTO]2.0.CO,2

MazgAJSKI, T. D. (1998): Nest-site characteristic of Great Spotted Woodpecker Dendrocopos major in central Poland. - Polish Journal of Ecology 46: 33-41.

Melletti, M. \& Penteriani, V. (2003): Nesting and feeding tree selection in the endangered White-backed Woodpecker. - The Wilson Bulletin 115: 299-306. https://doi. org/10.1676/03-022

MichalczuK, J. (2014): Expansion of the Syrian Woodpecker Dendrocopos syriacus in Europe and Western Asia. - Ornis Polonica 55: 149-161.

Michalczuk, J., Boruchalski, D., Mazurek, P., Mazurek, M., Michalczuk, M. \& Cymbaea, R. (2018): Woodpeckers Picidae in the agricultural landscape of the eastern part of Zamość Region. - Ornis Polonica 59: 231-249. [in Polish]

Michalczuk, M. \& Michalczuk, M. (2005): Feeding habits of the Syrian Woodpecker. British Birds 98: 378.

MichalczuK, M. \& Michalczuk, M. (2006a): Reaction on playback and density estimations of Syrian Woodpecker Dendrocopos syriacus in agricultural areas of SE Poland. Acta Ornithologica 41: 33-39. https://doi.org/10.3161/068.041.0109

Michalczuk, M. \& Michalczuk, M. (2006b): The usefulness of the mapping method with playback in estimation of the numbers of the Syrian Woodpecker Dendrocopos syriacus. - Notatki Ornitologiczne 47: 175-184. [in Polish]

Michalczuk, M. \& Michalczuk, M. (2011): Syrian Woodpecker Dendrocopos syriacus in the Upper Huczwa River Watershed in 2004-2006. - Chronmy Przyrodę Ojczysta 67: 426-432. [in Polish]

MichalczuK, M. \& Michalczuk, M. (2015): Decline of the Syrian Woodpecker Dendrocopos syriacus population in rural landscape in SE Poland in 2004-2012. - Ornis Polonica 56: 67-75. [in Polish]

Michalczuk, M. \& Michalczuk, M. (2016a): The reproductive biology of the Syrian Woodpecker Dendrocopos syriacus in a newly colonized area of south-eastern Poland. Journal of Ornithology 157: 179-187. https://doi.org/10.1007/s10336-015-1265-7

Michalczuk, M. \& MichalczuK, M. (2016b): Differences in reproductive investment between male and female Syrian Woodpeckers Dendrocopos syriacus. - Acta Zoologica Bulgarica 68: 77-84.

Michalczuk, M. \& Michalczuk, M. (2016c): Habitat preferences of Picidae woodpeckers in the agricultural landscape of SE Poland: Is the Syrian Woodpecker Dendrocopos syriacus colonizing a vacant ecological niche? - North-Western Journal of Zoology 12: $14-21$.

Michalczuk, M. \& Michalczuk, M. (2016d): Coexistence of Syrian Woodpecker Dendrocopos syriacus and Great Spotted Woodpecker Dendrocopos major in nonforest tree stands of the agricultural landscape in SE Poland. - Turkish Journal of Zoology 40: 743-748. https://doi.org/10.3906/zoo-1601-13 
Michalczuk, M. \& Michalczuk, M. (2016e): Nesting preferences of Syrian Woodpeckers Dendrocopos syriacus in the agricultural landscape of SE Poland. - Acta Ornithologica 51:71-81. https://doi.org/10.3161/00016454AO2016.51.1.006

MichalczuK, M. \& MichalczuK, M. \& Cymba£A, R. (2011): The usefulness of various methods of monitoring the population size of the Syrian Woodpecker Dendrocopos syriacus. - Ornis Polonica 52: 280-287. [in Polish]

Pasinelli, G. (2006): Population biology of European woodpeckers: a review. - Annales Zoologici Fennici 43: 96-111. https://www.jstor.org/stable/23735922

Pasinelli, G. (2007): Nest site selection in middle and great spotted woodpeckers Dendrocopos medius and D. major. Implication for forest management and conservation. Biodiversity and Conservation 16: 1283-1298. https://doi.org/10.1007/s10531-007-9162-x

Ruge, K. (1969): Beobachtungen am Blutspecht Dendrocopos syriacus im Burgenland. Vogelwelt 90: 201-223.

Schepps, J., Lohr, S. \& Martin, T. E. (1999): Does tree hardness influence nest-tree selection by primary cavity nesters? - Auk 116: 658-665. https://doi.org/10.2307/4089327

SzlivkA, L. (1957): Von der Biologie des Blutspechts Dendrocopos syriacus balcanicus, und seinen Beziehungen zu den Staren, Sturnus vulgaris. - Larus 9/10: 48-70.

SzlivkA, L. (1962): Weitere Angaben über den Blutspecht aus der näheren Umgebung von Gunaroš. - Larus 14: 121-134.

Walankiewicz, W., Czeszczewik, D., Mitrus, C. \& Bida, E. (2002): Snags importance for woodpeckers in deciduous stands of the Białowieża Forest. - Notatki Ornitologiczne 43: 61-71. [in Polish]

WesoŁowski, T. (1995): Ecology and behaviour of White-backed Woodpecker (Dendrocopos leucotos) in a primaeval temperate forest (Białowieża National Park, Poland). - Die Vogelwarte 38: 61-75.

Zavialov, E., Tabachishin, V. G. \& Mosolova, E. Y. (2008): Expansion of Syrian Woodpecker in European Russia and Ukraine. - Dutch Birding 30: 236-238.

Received April 3, 2019, accepted February 29, 2019, published May 15, 2020 